\title{
Repairing Broken Relations by Repairing Broken Treaties: Theorizing Post-Colonial States in Settler Colonies
}

\author{
XAVIER SCOTT \\ York University, Canada
}

\begin{abstract}
This article examines the British colonial theft of Indigenous sovereignty and the particular obstacles that it presents to establishing just social relations between the colonizer and the colonized in settler states. In the first half, I argue that the particular nature of the crime of sovereign theft makes apologies and reparations unsuitable policy tools for reconciliation because Settler societies owe their very existence to the abrogation of Indigenous sovereignties. Instead, Settler states ought to return sovereignty to the land's Indigenous peoples. In the second half of this paper, I take up some of the practical questions of how this might be done and anticipate a number of objections. Giving up sovereignty would not mean dispossessing the millions of colonists who currently reside in these countries of their homes and property but it does mean rethinking the constitutional makeup of a country and how that serves to benefit the different peoples who make their homes there.
\end{abstract}

KEYWORDS Indigenous sovereignty; reconciliation; settler colonialism; democracy; social justice

Contemporary Settler-colonial states consider themselves some of the freest and most democratic societies in the world and yet their foundations are illegitimate. This illegitimacy haunts them in the form of history books that begin in the sixteenth century, a reservation system that dots nations of incredible wealth with communities that are subject to some of the worst social problems in the world, and ongoing lawsuits against the state over broken treaties and genocidal policies of assimilation. In order to repair these broken relationships, reparations programs, truth and reconciliation proceedings, and formal apologies have been undertaken by the colonial states. However, Glen Sean Coulthard challenges the idea that relations 
between Settlers and Indigenous peoples can be transformed through the politics of recognition, ${ }^{1}$ because "this orientation to the reconciliation of Indigenous nationhood with state sovereignty is still colonial insofar as it remains structurally committed to the dispossession of Indigenous peoples of our lands and self-determining authority" (Coulthard, 2014, p. 151; emphasis in original). Indeed, a number of Indigenous academics and activists have argued that the state cannot be an effective institution to achieve reconciliation between Settlers and Indigenous peoples because the very existence of these settler states is predicated on the cultural destruction of Indigenous peoples. As Andrea Smith (2005, p. 185) points out, "it is consistent practice among progressives to bemoan the genocide of Native peoples, but in the interests of political expediency, implicitly sanction it by refusing to question the legitimacy of the settler nation responsible for this genocide." In this spirit, I want to look at what the legal ramifications might be of asserting Indigenous sovereignty over and above the illegitimately acquired sovereignty of the settler colonial states. I will argue that both legal and moral justice require that we reassert Indigenous sovereignty and that doing this requires a commitment to return colonized territory to Indigenous peoples.

My goal in this paper is to argue, on ethical grounds, that justice will only be found in the full recognition of the sovereign rights of various Indigenous peoples, which extend over the entire territory that is currently occupied by Settler-colonial states. I take this approach not because I think international law is an avenue that can be expected to achieve justice for Indigenous people but because there is something distinct about the sovereign nature of the colonial relationship. I begin by outlining the history of sovereignty doctrine as it emerged in discourses surrounding international jurisprudence. I argue that the way in which sovereignty was articulated was designed to

\footnotetext{
${ }^{1}$ My focus in this article are the legal relationships between "Settler state sovereignty" and "Indigenous sovereignty." I am not talking about "Settlers" as Caucasian, Anglo-Saxons, necessarily, as Settlers have come from around the world to make their homes in colonial states. Nor am I talking about Indigenous peoples as an ethnic, linguistic or cultural group. In Canada alone, Indigenous peoples speak over 50 languages, from 12 distinct language families that contain as much variation as European and Asian languages (Borrows, 2002, p. 3). As Duane Champagne notes, the only generalization one can make about Indigenous communities "is that they have persisted" (Champagne, 2005, p. 9). I am most familiar with examples from within what is now Canada but, for reasons discussed below, contesting colonial borders as illegitimately established precludes confining my argument to contemporary Canadian geography. The term "Settlers" will refer to those who see the colonial state as the highest political authority in North America. The term "Indigenous peoples" will refer to the many peoples who have had their sovereignty stolen from them. When I am talking about a specific ethnic or cultural group, however, I will adopt the more specific term to avoid conflating the specific characteristics of the group with the colonial identity that has been forced upon them. Thus, Settlers have consistently denied the sovereignty of Indigenous peoples, to which many of them, such as the Cherokee, have responded with resistance.
} 
create a form of quasi-sovereignty for Indigenous peoples that justified their displacement and allowed the formation of colonial governments that predicated their existence on the abrogation of Indigenous sovereignty. Moreover, the quasi-form of sovereignty currently granted to Indigenous peoples in these countries is the legacy of the form it originally took, and continues to justify policies of assimilation and cultural destruction. I propose a shift, whereby Settlers use international law and transitional justice studies to think about reconciliation with Indigenous peoples, rather than approaches that aim to achieve justice for Indigenous peoples within the confines of the colonial state. ${ }^{2}$ International law provides tools to recognize the illegal nature of the original "theft of sovereignty" (as I am calling it), while transitional justice studies provide a number of precedents for how states with genocidal policies can move out of their violent pasts into post-colonial futures.

The idea of disbanding the Settler states that currently exist in these colonial territories might seem extreme, but extreme action is what is required by the enormity of the crimes that have been committed against Indigenous peoples. It may also strike many that calling for the dissolution of the colonial states is neither practical nor likely. Moreover, as Indigenous legal scholars like Douglas Sanderson (2014) of the Opaskwayak Cree Nation argue, it is sometimes better to work within an imperfect system of law such as the Indian Act, than it is to hold out for a perfect system of justice because even small changes can make meaningful differences in people's lives. This is in stark contrast to scholars such as Taiaiake Alfred (2005) and Glen Coulthard (2014), who argue that engaging with colonial structures on their own terms is a self-defeating exercise. As a white colonial outsider, my aim is not to enter into debates about strategy amongst Indigenous scholars, leaders, and activists. They can and are making their own choices about how to pursue freedom and flourishing for themselves and their peoples. My goal here is to show Settlers that by their own legal and ethical standards - used to applaud the de-Nazification of Germany, the end of apartheid in South Africa, or the recognition of the post-Yugoslavian states - we have an ethical duty to protect the communal rights of Indigenous peoples, even if this means abandoning our attachment to the colonial state.

While the implementation of such a change will no doubt face a large number of obstacles, such obstacles are by no means impossible to overcome and would constitute an important step in reconciliation between Indigenous

\footnotetext{
${ }^{2}$ I say Settlers here, because the target audience for this article are Settler colonists. Indigenous scholars and activists have a far greater understanding of the colonial obstacles confronting them and the best tactics to pursue freedom under colonial conditions than I could hope to present. Yet Indigenous peoples are already doing most of the work of reconciliation - and they are the victims of the colonial relationship! At the Canadian Philosophical Association's (2018) plenary session on Reconciliation in the Academy, Douglas Sanderson noted the burden that testifying in panels on reconciliation places on Indigenous peoples. Settlers are the ones who broke their relationships with Indigenous peoples and, while it is important to listen to Indigenous elders and activists to plot the path towards reconciliation, Settlers must begin sharing the burden of reconciliation.
} 
peoples and their colonial occupiers. Anyone seeking a quick and easy solution to half a millennia of policies of genocide and cultural assimilation ought to look elsewhere, as my goal in writing this is to disrupt the typical narrative of "these harms happened in the past and there is nothing that can be done now that would not be unfair towards the settler populations that now live in these countries," which colonial societies have used to justify the continuation of policies of assimilation and dispossession.

\section{Sovereign Theft}

This section of the paper will outline a particular form of sovereign violence that was done to Indigenous societies. While Indigenous societies have been the victims of a number of types of violence, ${ }^{3}$ the form of sovereign violence that is the focus here is noteworthy in three respects: first, it placed colonial sovereignty at the heart of the international legal system; second, it simultaneously served as the basis for delegitimizing Indigenous sovereignty; and finally, it later served as the justification for numerous other forms of violence.

Sovereignty can be defined as: the concept of a nation, whose people invest a supreme authority with a monopoly over the legitimate use of violence, which has absolute legal jurisdiction over a given territory, and is recognized by other sovereign states. ${ }^{4}$ Both the philosophical concept of sovereignty and its formalization as a key principle in international law have been linked to Europe's invasion of the Americas (Anghie, 1996; Moloney, 2011). Much of the theory of sovereignty, as it emerged in early-modern Europe, was designed to distinguish European, imperial violence from Indigenous violence, which takes place in the "state of nature." This contrast was designed to promote peace through the rule of law in Europe, even as it created a frontier mentality that encouraged colonization and genocide in the "New World."

\footnotetext{
3 Andrea Smith (2005) documents the use of sexual violence as a means of carrying out Indigenous genocide. Bonita Lawrence (2004) documents the use of racist notions of Indigeneity as inscribed in Canada's Indian Act to deny Indigenous people membership in their own communities. Coulthard (2014) argues that attempts to reconcile with Indigenous peoples in Canada using a politics of recognition are in fact the most recent attempt at Indigenous assimilation.

${ }^{4}$ This definition combines legal notions of sovereignty doctrine with the concept's political foundations. The "nations" of early-modern Europe were just beginning to imagine themselves and political philosophers such as Bodin and Hobbes were attempting to develop political theories capable of forestalling conflict by investing absolute authority (previously reserved for God) in the sovereign. While sovereigns never exercised this degree of control in practice, the theories did lay the ground for legal theorists such as Vitoria and Grotius to establish sovereignty as the basis for international law.
} 
Francisco de Vitoria was shocked at the depredations of the conquistadores in the new world and sought to create a system of international law adapted to the different cultural contexts of Europe and the (still Indigenous) Americas (Anghie, 1996). This meant that he had to find a basis for international law that was not religious. Vitoria attributes the right to property and rationality to indigenous peoples - the two means that had hitherto justified colonization. Edward Keene comments:

Vitoria, however, left Europeans in the situation where they had to show such a degree of respect for other peoples' sovereignty and property that, if taken seriously, it would imply handing back the lands the Spanish had conquered in the Americas and would have put a halt to earlier colonialism. (Keene, 2002, p. 55)

Spain and the other colonial powers would not accept this and, while the concept of sovereignty was maintained in international law, it increasingly took on a Eurocentric form. Rather than representing a means by which different cultures could interact peacefully, sovereignty entrenched a hierarchy between European sovereigns and Indigenous peoples in the rule of law.

Regardless of Vitoria's intent, Antony Anghie's (1996) study of his work finds that it actually laid the groundwork for the eventual conquest of Indigenous peoples. Eschewing the traditional justification for colonization (the universal jurisdiction of the Pope), Vitoria sets out to construct a model of international law based on principles of natural law administered by a secular sovereign in accordance with the principles of reason - a jus gentium (law of nations). Vitoria ascribes two characteristics to the Indigenous personality. First, because they possess reason, they belong to the same universal realm of jus gentium as the Spanish; second, they are notably distinct from the Spanish because their social and cultural practices are at variance with the universal (Christian) norms practiced by the Spanish. For Vitoria: "The discrepancy between the ontologically 'universal' Indian and the socially, historically 'particular' Indian must be remedied by the imposition of sanctions which effect the necessary transformation" (Anghie, 1996, p. 327). Vitoria used just war theory to transform the particular Indian into one obeying Christian (European) norms. In a shocking reversal of his attempt to construct a theory of international law that was free of religious interpretation, Vitoria comes to the conclusion that only Christian sovereigns can wage a just war - otherwise the wars of the Saracens against the Christians might also appear just. Thus,

Vitoria's insistence, in his analysis on just war, that only Christian subjectivity is recognized by the laws of war, ensures that the Indians are excluded from the realm of sovereignty and exist only as the objects against which Christian sovereignty may exercise its power to wage war. (Anghie, 1996, p. 330) 
Indigenous sovereignty is established only for the sake of justifying their conquest and assimilation into the universal order of jus gentium. It is necessary to grant a quasi-form of sovereignty to them because if they retained full sovereignty, then the conquest of their lands would be illegitimate, while if they were granted no sovereignty at all then subsequent generations could point to the arbitrary injustice of this fact. They have just enough sovereignty to enter into treaties that legitimate the occupation of their land and establish the sovereign authority of the colonial powers, but not enough to meaningfully exercise their sovereign right to territorial control. Moreover, whenever there is a dispute between the colonial power and the Indigenous community, it is the legal system of the colonial power that prevails.

Hugo Grotius further developed sovereignty as a principle of international law in his work On War and Peace (2012) which is credited with helping to end the "Wars of Religion" in Europe with the peace of Westphalia (Taylor, 1998). Keene notes two themes in Grotius's work that enabled and promoted colonialism - the right of individuals to appropriate "unoccupied" land and the divisibility of sovereign power (Keene, 2002, p. 3). By the $19^{\text {th }}$ century, unoccupied territory included anywhere that lacked a colonial European government. As the prominent $19^{\text {th }}$ century jurist Lorimer put it:

He [the international jurist] is not bound to apply the positive law of nations to savages, or even to barbarians, as such; but he is bound to ascertain the points at which, and the directions in which, barbarians or savages come within the scope of partial recognition. (Lorimer, 1883, quoted in Anghie, 1999, p. 39)

The divisibility of sovereignty in the case of non-Europeans allowed colonial states to grant them partial recognition in the form of quasi-sovereignty, thereby enabling the local people to enter into treaties that they could be punished for violating (through just war doctrine) but which could be unilaterally broken by the colonial power once they were no longer politically expedient. Since all the nations of the world are part of a single international community, no country has the right to invade any other. Yet that community was not founded on universal principles, but was based on a European consensus. Since recognition was the basis for membership in the "international community" and the original members of the jus gentium were all European (in practice, if not in theory), the Westphalian system would seem to promote conquest and colonialism abroad, even as it promoted mutual recognition within Europe. The legacy of the Westphalian peace has been a system that simultaneously maintains the historical legality of colonialism, while rejecting it as a principle of justice.

The origins of international law were inherently unjust and based on a racist refusal to acknowledge Indigenous sovereignty in its entirety. 
However, in recognizing the moral and legal chicanery that was required to deny Indigenous sovereignty, we can lay the groundwork for understanding the sovereign violence that European powers committed and how that was then tied to the numerous forms of injustice committed afterwards. Not only did Indigenous peoples have political societies, but European sovereigns and jurists regularly recognized their sovereignty by signing over 800 treaties with different Indigenous communities (Kickingbird, 1995). Siegfried Wiessner (1995) divides the treaty-making conventions between the United States and Indigenous communities into two time periods - prior to and following the end of the War of 1812. Prior to this date, treaties were concluded on a relatively equal basis. They fully recognized the Indigenous governance structures and were ratified by the U.S. Senate using the language of international law. Once the threat of other colonial powers was over, treaties became increasingly used "to regularize and channel the removal of Indians from their traditional vast hunting and fishing grounds to ever smaller, ever more barren areas of land" (Wiessner, 1995, p. 577). The War of 1812 marks a switch from the nation-to-nation relationships that characterized earlier agreements, to a new species of treaty which deprived Indigenous communities of nationhood.

I call the means by which colonial states appropriated Indigenous sovereignty "theft," since it deprived Indigenous peoples of their right to selfdetermination and full use of their traditional territories. Moreover, the quasisovereignty that was granted to Indigenous peoples made the destruction of their communities a requirement to establish the legitimacy of the colonial power's occupation. Taiaiake Alfred and Jeff Corntassel argue that contemporary settlers are no longer trying to eradicate Indigenous peoples as bodies, but rather "as peoples through the erasure of the histories and geographies that provide the foundation for Indigenous cultural identities and sense of self" (2005, p. 598; emphasis in original). This is both a continuation of the desire to appropriate Indigenous land and an attempt to foreclose the possibility that land that has already been annexed by colonists be returned. Indigenous sovereignty in its current form in the British colonial states continues to act as a form of "quasi-sovereignty" the goal and legacy of which are the assimilation and destruction of Indigenous peoples.

The Truth and Reconciliation Commission of Canada (2015) has outlined the crimes the Canadian government committed against Indigenous peoples. While the summary of their findings focuses on the cultural genocide the Canadian state engaged in through residential schools, it acknowledges the physical and biological genocides engaged in by the state as well. It states:

Canada asserted control over Aboriginal land. In some locations, Canada negotiated Treaties with First Nations; in others, the land was simply occupied or seized. The negotiation of Treaties, while seemingly honourable and legal, was often marked by fraud and coercion, and Canada was, and remains, slow to implement their provisions and intent. (Truth \& Reconciliation Commission of Canada, 2015, p. 1) 
Australian Prime Minister Kevin Rudd (2008) issued an apology for the "Stolen Generation," which took Aboriginal and Torres Strait Islander children from their families. The U.S. issued its apology to Indigenous peoples, hidden in section 8113 of a 2010 Defense Appropriations Act. It acknowledges "that there have been years of official depredations, illconceived policies, and the breaking of covenants by the Federal Government regarding Indian tribes" and also "many instances of violence, maltreatment, and neglect inflicted on Native Peoples by citizens of the United States" $\left(111^{\text {th }}\right.$ Congress, 2009, s.8113). All three of these apologies profess a desire to "remove a stain from its past" (Truth \& Reconciliation Commission of Canada, 2015, p. 237), for "the nation to turn a new page" (Rudd, 2008), and look towards a future "where all the people of this land live reconciled as brothers and sisters" (111 ${ }^{\text {th }}$ Congress, 2009, s.8113). Yet the Australian apology made no reference to reparations, the American apology contains a disclaimer that nothing in it is meant to "serve as any settlement against the United States" (111 ${ }^{\text {th }}$ Congress, 2009, s.8113), and while Canada has attached its apology to court mandated reparations payments, it has failed to reform its relationship with Indigenous peoples by (for example) reforming the 1876 Indian Act.

The existence of sovereignty in a colonial context is predicated on the nonsovereignty of Indigenous peoples. At best, they are granted a form of "quasisovereignty" that is not taken seriously by the international state system and is generally considered to be a temporary stage in the integration of Indigenous peoples into the colonial state. ${ }^{5}$ The quasi-status of their sovereignty is not a step on the path towards full sovereignty, but towards destruction and the seamless transfer of sovereignty from them to the colonial state. In their critique of the literature on post-colonial theory and antiracist work, Bonita Lawrence and Enakshi Dua ask, "what does it mean to look at Canada as colonized space?" (2005, p. 123). Because settler states are founded on policies that combine extermination and assimilation, the continued existence of Indigenous peoples as peoples depends on the full recognition of their inherent sovereignty. For this reason:

To speak of Indigenous nationhood is to speak of land as Indigenous, in ways that are neither rhetorical nor metaphorical. Neither Canada, nor the United States - or the settler states of "Latin" America for that matter - which claim sovereignty

\footnotetext{
${ }^{5}$ One example of how the international system refuses to recognize Indigenous sovereignty occurred when the Iroquois Lacrosse team attempted to travel to England to participate in the Lacrosse World Championship in 2010. The UK refused to admit them because the British government does not recognize passports issued by the Iroquois Confederacy - despite recognizing them in the 1758 Treaty of Easton.
} 
over the territory they occupy, have a legitimate basis to anchor their absorption of huge portions of that territory. (Lawrence \& Dua, 2005, p. 124)

To claim respect for Indigenous sovereignty, therefore, is to deny the legal legitimacy of Settler colonies. This is because of the territoriality and legal supremacy claims of sovereign states.

While the development of international law has served to strip Indigenous peoples of their traditional lands, it also contains a number of mechanisms that have been used in other contexts of occupation, violence, and genocide. First, the principle of pacta sunt servanda is the cornerstone of international law (Uribe, 2010; Wiessner 1995) - states are required to abide by their word. The fact that colonial powers broke their treaties with Indigenous governments ought not to mean that it is thereby nullified, but rather that "there may be legal consequences" (Kickingbird, 1995, p. 603). Furthermore, the principle of sovereignty contains a right to reassert authority when territory is unjustly annexed. When a state's sovereignty is violated, international law calls for its restoration. Following Kirke Kickingbird, I believe that "treaties form the backdrop of the past, confirm rights in the present and provide the basic definition for the evolving future" (1995, p. $605)$. Only by respecting the traditional rights of Indigenous peoples including rights to their territories - can colonial states repair the sovereign wrong done in the abrogation of their duty to stand by their treaties.

\section{Transitional Justice}

I believe that a transitional justice lens can offer insight into how to approach reconciliation between Settlers and Indigenous peoples. There are a number of ways in which the harm caused to the relationship is similar to other contexts in which injustice has been practiced, such as post-genocide Rwanda, post-War Germany, and post-apartheid South Africa. However, I will also note some of the differences between Settler-colonialism and some of these other contexts - specifically, that liberal democracies were perpetrators of the wrongs done to Indigenous peoples and therefore a "transition" to a liberal-democracy (without attending to the communal rights of Indigenous peoples) will not accomplish what the history of sovereign theft and treaty abrogation call for.

Transitional justice studies can help with the process of reconciliation between Settlers and Indigenous peoples because its objects of study are histories of extreme, even genocidal, levels of violence. The primary question it seeks to answer is: "How should societies deal with their evil pasts?" (Teitel, 2000, p. 3). Post-war Germany, former soviet states in Eastern Europe, dictatorships in Latin America, and post-apartheid South Africa are some of the most famous examples of such transitions (MacLachlan, 2012; Teitel, 2000). Apologies, reparations programs, criminal prosecutions, and 
truth commissions are the means to accomplish reconciliation (Gray, 2010). However, typical in the literature on transitional justice is the assumption that the offending government was not a liberal democracy and that some sort of major shift has taken place between the old regime and the new (Teitel, 2000; Verdeja, 2007). In the case of colonial Settler states, however, many of the injustices (particularly that of sovereign theft) were perpetrated by liberaldemocracies. While transitional justice studies have developed a number of the moral and political principles useful in assessing the prospects of reconciliation between Settlers and Indigenous peoples, the assumption that liberal-democratic regimes are the solution to, rather than the cause of, such abuses must be critically re-examined.

Liberal theorists of transitional justice have a tendency to focus on individual perpetrators and victims and yet "there are some situations in which it is simply the case that entire groups have either participated in wrongdoing or passively acquiesced, while benefitting from the results" (MacLachlan, 2012, p. 51). Attending to the communal harms perpetrated against a community is often as important as seeking justice by prosecuting individual perpetrators. In his review of Reconciliation Through Truth, Mahmood Mamdani (1996) critiques the comparison of the Holocaust to apartheid. The best way to understand the legacy of apartheid, Mamdani argues, is not in terms of the perpetrator/victim relationship, as in the case of the Holocaust, but in terms of the beneficiary/victim relationship. In the case of apartheid, as in the case of the occupation of Indigenous land, it is important to focus not only on the individuals who exercised violence against victims, but the violence inherent in a system that was established for the benefit of whites at the expense of non-whites.

Similarly, democratic structures in contemporary Settler-states offer little hope for justice to Indigenous peoples. Democracy is the great transformer in the literature on transitional justice. For example, Ruti Teitel's (2000) work assumes that the injustices that took place in the transitional society occurred in a context of authoritarianism and that the transition to democracy will involve a particular set of policy tools designed to hold the leaders of the previous regime responsible (without being draconian). In colonial contexts, however, many of the injustices that took place happened once democracy had been established by the colonial government. Furthermore, time and numbers are both on the side of the colonial power. The more people who immigrate to a settler colony, the more disempowered the Indigenous population are in a democratic forum. ${ }^{6}$ Unlike South Africa, more democracy

\footnotetext{
${ }^{6}$ Guthrie Valaskakis examines the complex obstacles to understanding questions of identity and Indigeneity. Drawing on David Foster, she notes "that the number of people who identity [sic] themselves as Indian on US census records has nearly tripled since 1970, but Indian bloodlines are thinning. 'One federal study estimated that the percentage of Indians who are full-bloods sixty percent in 1980 - will fall to thirty-four percent in 2000 and to three-tenths of one percent
} 
will not result in the implementation of policies that will redress either the original theft of sovereignty, or the slew of genocidal policies enacted in order to solidify that original theft.

Since 1996 Canada has tried to develop a transitional justice framework to promote reconciliation with Indigenous communities by focusing on "forgiveness" and "reconciliation" (Coulthard, 2014). Coulthard notes that the difference between the Canadian context and the transitional contexts popular in the literature (e.g., South Africa) is that a "formal transition" has occurred in the other contexts but not in Canada. He argues that "where there is no formal period marking an explicit transition from an authoritarian past to a democratic present - state-sanctioned approaches to reconciliation tend to ideologically fabricate such a transition by narrowly situating the abuses of settler colonization firmly in the past" (p. 22; emphasis in original). This was a distinctive feature of the American, Canadian, and Australian apologies noted above. Drawing on the anti-colonial work of Franz Fanon, Coulthard argues that the ongoing resentment felt by many Indigenous peoples is an important sign of "moral protest and political outrage" (2014, p. 22). This is because Settler-states refuse to dismantle the ongoing institutions of colonization, even as they express regret about the "past-effects" of such institutions. Apologies are excellent ways of making up for past wrongs; however, in this instance neither really addresses the nature of the ongoing dispossession of Indigenous sovereignties.

The sovereign power that owes its existence to the theft of Indigenous sovereignties cannot apologize for an injustice it continues to practice by virtue of its very existence. Particular abuses that no sovereign power ought to engage in can be apologized for, but this fails to address the particular wrong that afflicts Indigenous peoples as collectives. How can a Canadian court (representing Canada's sovereign power) objectively and in accordance with our notions of justice determine the value of the dispossession of Indigenous sovereignty? There are many other forms of injustice that similarly cannot be atoned for in a way that is symmetrical with the original wrong. However, in other cases of injustice that involve the illegal exercise of sovereign power our sense of justice is such that it always involves a restoration of sovereign power to the dispossessed group (e.g., Kuwait, or South Korea) and where such restoration is impossible, the designation of "occupied territory" status maintains the illegitimacy of the occupation (e.g., Western Sahara and the Occupied Territories around Israel). Democracy,

in 2080" (Foster, 1997, cited in Valaskakis, 2000, p. 393). Combine this with the fact that Indigenous peoples have been forced to conceptualize their identity primarily in terms of their legal status with the government in ways that collapse race, culture, and character leads genetic assimilation to cultural assimilation and, hence, destruction as a people. "The evolutionary theories and racially based notions that emerged at the turn of the twentieth century to qualify, and classify, Indians reflect the concepts of purity and authenticity that are entrenched in the legal systems of the United States and Canada, where they not only frame Indian political and territorial dependence, but define Indians themselves" (Foster 1997, cited in Valaskakis, 2000, p. 393). 
apologies, and reparations are all excellent responses to histories of injustice, but are not suited to addressing the theft of sovereignty from Indigenous peoples.

What we are missing in the set of policy tools we are currently using to restore right relations with Indigenous peoples is a transition. Since Settlerstates only exist as the result of broken treaties and the promise of and then unilateral withdrawal of sovereign recognition, attending to that particular feature of the wrongs done to Indigenous peoples will be required for reconciliation. To leave the legal identity and constitutional basis of the state untouched, even as we seek reconciliation is to say: "yes, mass murder took place, but it's not that important - it should weigh very little in our final judgements; it should affect very little what we do in the world" (Zinn, 2003, p. 8). One of the factors that marks a transition out of a violent past is the rewriting of a constitution and the founding of a new set of norms and institutional practices (Teitel, 2000). According to Teitel, "transitional constitution making comprehends the codifying, entrenching purposes associated with constitutionalism and also the transformative, disentrenching purposes peculiar to transitions" (2000, p. 219). When the oppressive policies of a state reach a certain level of violence, we expect a formal transformation of the government in order to provide a fresh basis for the establishment of right relations. That the liberal-democratic constitutions of Canada or the United States ought to provide Settler-states with an exception to the need for a transition seems bizarre and predicated solely on a desire to ignore the wrongs of the past. Reconciliation will require Settlers to challenge their assumptions that the colonial state can find a legitimate path towards reconciliation and that there is no way to give sovereignty back to the people from whom it was taken. The colonial states have had 500 years to work out a program of reconciliation. It is now time for a different government to have the opportunity. What better government than one made up of those dispossessed by the colonial regime?

\section{Post-Colonial States}

I anticipate a number of objections to my proposal and will attempt to assuage some of the misgivings that people have about the need for a transfer of sovereignty. Some of the ideas for the re-founding of the state that I put forward will appear programmatic. However, the intention is not that they be taken as a road-map for what a post-colonial state will look like. Rather, my goal is to demonstrate ways in which these colonial states already recognize the collective rights of settler communities in ways that are undemocratic, Eurocentric, and deny the same recognition to Indigenous peoples. 
First, it may be objected that the notion of territory and borders implies the adoption of a colonial mentality, which is precisely what Indigenous activists are trying to combat. This is a valid objection, but I don't believe it is insurmountable. As post-colonial theorists have demonstrated in their studies of the decolonization of Africa and Asia, the nation-state form is a European "derivative discourse" that has maintained many of the power relations of colonial society (Chatterjee, 1993). However, a post-colonial situation seems preferable to one of ongoing colonialism. Moreover, while the concepts of territory and borders have distinctly colonial histories, they also contain within them the possibility to rethink the ways in which they are understood. For example, while colonial notions of property and borders have been exercised in ways promoting the exploitation of the land (Coulthard, 2014), it is possible that they be reapplied to promote responsible stewardship. While such borders have traditionally been used to keep Indigenous people divided, it is possible to redraw them and reimagine their relations with one another. For example, borders between the provinces of Canada are regulated differently from how the US manages the borders between their states and the border between Canada and the US is treated differently from the border between Spain and France. Post-colonial states may agree to federate (or not) on the basis of what they believe will create the best post-colonial situation for them. It may be that North America is broken up into hundreds of states. It may be that Indigenous societies elect not to take constitutional responsibility for Settlers and establish states for Settlers that rely on their existing constitutions - though in territories now criss-crossed by hundreds of independent Indigenous states. It may be that post-colonial Indigenous societies agree to some sort of federation that creates conditions for interdependence and cooperation at the same time as they protect autonomy and self-management. Transitional justice is complex and transformative, balancing normative considerations of justice with political pragmatism. ${ }^{7}$

A frequent argument against acknowledging Indigenous sovereignty admits that the original theft was wrong, but argues that does not justify the expulsion of Settlers and the confiscation of their homes and property. Similar to the arguments based on "ethical individualism" launched against those seeking reparations for slavery (Gray, 2010, p. 59), this would involve an unjust notion of intergenerational guilt that does not fit with liberal notions of justice. But this assumes that Indigenous people would be as violent and uncompromising as Settlers were in the exercise of their sovereign powers.

\footnotetext{
${ }^{7}$ It is useful to draw on Darrel Moellendorf's (2007) political understanding of reconciliation as a social goal that can be pursued through public policy options. "This approach," he explains, "takes reconciliation to be a normative political ideal that is less than the whole of social justice, but that offers a basis for reasonable hope that further justice is within the reach of those pursuing it by constitutional means" (p. 206). Moellendorf's political understanding of reconciliation is useful because it manages our expectations about what the end result of the transfer of sovereignty will be. Transferring sovereignty will not be a magic wand solution that restores right relations between the colonizer and the colonized; however, it can create the postcolonial conditions that are necessary to move in that direction.
} 
"It is interesting to me," Andrea Smith opines, "how non-Indians often presume that if Native people regained their landbases, that non-Indians would be exiled from those land bases. Yet a much more inclusive vision of sovereignty is articulated by Native women activists" (2005, p. 186). A just transfer of sovereignty will not involve the forced relocation of Settlers. It may involve land redistribution policies and it may involve a different constitutional relationship with the land that precludes destructive resource extraction projects. Neither of these constitute the horrors of dispossession and relocation experienced by (for example) the Cherokee during the Trail of Tears.

Moreover, it is important to note the difference between sovereign territory and personal property. Sovereign territory can be transferred without the transfer of private property. When South Africa rewrote their constitution, it protected the property of the white colonists, despite the fact that it was largely acquired illegitimately. This was done both to avoid the pitfalls of attributing individual guilt for collective crimes and to guarantee economic stability after the transition. However, this is not to say that property relations remain the same in a post-colonial state. South Africa's post-apartheid government began with land reform efforts that even now, more than two decades later, are a continued source of frustration for landless black South Africans (Harding, 2018). Typically, a change in sovereignty will involve a change in the laws governing taxation and other legal notions surrounding private property. This is a far cry from forcing the settlers to leave and claiming their property for Indigenous people; however, Settlers should be prepared for a major restructuring of their previous rights over the land. Family cottages on the traditional lands of Indigenous peoples may be appropriated under legal doctrines similar to eminent domain and resource extraction projects near Indigenous communities may undergo increased scrutiny.

Another objection contends that it would be undemocratic to place political power into the hands of a minority of the population. Yet the transfer of sovereignty does not mean an end to democracy. Were sovereignty to be transferred to the Indigenous peoples living in settler countries, it is nearly impossible to imagine that they would not choose to implement a democracy - simply because the majority of people currently living inside their borders would not accept anything else. In fact, part of the reason for a transfer of sovereignty is to found states that are more democratic, by virtue of their responsiveness to Indigenous legal traditions. John Borrows discusses how Canada's representative democracy marginalizes Indigenous participation in politics, by placing them between provincial and federal jurisdictions (Borrows, 2002, p. 44). Civic equality is the goal, but in the wake of such a long history of dispossession sometimes corrective measures are needed to arrive there (Moellendorf, 2007). There are a number of ways to accomplish 
this. One possibility is the implementation of a quota system that ensures a minimum number of Indigenous peoples are represented in government. New Zealand already has a system of dedicated electoral seats to the Maori population. In 1986 the Royal Commission on the Electoral System found that "the Maori seats have come to be regarded by Maori as an important concession to, and the principle expression of, their status as the Indigenous people of New Zealand" (New Zealand Parliamentary Library, 2009). Another option to increase Indigenous representation in government is to redraw political boundaries in a way that grants more legislative representation to Indigenous peoples and grants them greater autonomy over their communities. While this allows smaller numbers of people a greater share of representatives, it is not inherently undemocratic. New Jersey gets to elect as many Senators as California to the US Senate and a number of the Eastern provinces in Canada receive a greater allotment of parliamentary seats in government than their populations account for. These examples show that democratic states frequently distribute representatives on a regional basis rather than in proportion to their population.

The final consideration I would like to advance, and arguably the most important, is related to the reduction of social and economic differences between Indigenous and non-Indigenous peoples. Most of the specific policies designed to do this will be legislative in nature, rather than constitutional, and ought to be worked out by experts, civil society groups, and the democratic process. However, constitutionally increasing economic rights, particularly rights associated with access to services (health, education, and infrastructure), is one possible option for a post-colonial society attempting to set the stage for the elimination of the social and economic disparities that currently exist. An economic benefit of redrafting the political boundaries of a state is that it might give more control over the extractive industries to Indigenous communities. In his talk "The Economics of Reconciliation," Shawn A-in-chut Atleo notes that, "almost every resource development activity currently operating or planned [in Canada] is occurring within 200 kilometres of a First Nation community and in the middle of our traditional territories" (2012, p. 4). Given the role that natural resource extraction has played in the displacement of Indigenous peoples, greater control over these industries seems like a particularly appropriate means of redress. Moreover, the elimination of the social and economic gaps between settlers and Indigenous peoples might actually lead to tax savings relative to the current state of affairs. In Canada, for example, there has been research that shows that "closing the skills and education gap between First Nations and the rest of the population will generate $\$ 400$ billion within a generation and save Canada $\$ 150$ billion in social costs" (Atleo, 2012, p. 4). Reconciliation has pragmatic as well as moral dimensions when approached properly. 


\section{Conclusion}

There is a certain sadness that would accompany the death of the colonial sovereign and it is understandable that this is the case; however, there is a certain exuberance that ought to be associated with it as well. National communities might be imagined (Anderson, 2006), but they are communities nonetheless and the reticence that many Settlers might feel about the solution to the problem of sovereign theft outlined herein is entirely understandable. However, I hope that the case has been made that the obstacles confronting the establishment of fully sovereign Indigenous states are not insurmountable. Furthermore, it seems apparent that the current relationship between the governments of the English colonial states and the Indigenous peoples that live within their borders are not likely to be rectified using the policy options currently being employed. The reservation model that has been adopted by colonial governments belies a desire for the eventual assimilation of Indigenous peoples. Such assimilation would tragically complete the destruction of Indigenous communities that began in the $15^{\text {th }}$ century and we have a moral duty to keep that from happening.

Exuberance over the possibilities inherent in the founding of a new state is the attitude I would most like to cultivate with this paper. The establishment of right political relationships with Indigenous peoples ought to be seen as an incredible opportunity - the scale of which is akin to the fall of the Berlin Wall in its moral and pragmatic dimensions. As Taiaiake Alfred (2005, p. 35) notes:

If non-indigenous readers are capable of listening, they will learn from these shared words, and they will discover that while we are envisioning a new relationship between Onkwehonwe and the land, we are at the same time offering a decolonized alternative to the Settler society by inviting them to share our vision of respect and peaceful coexistence.

The symbolic importance of re-establishing the state along the lines offered above cannot be overemphasized. Settlers in these states would only enrich their sense of identity and history through the transfer of sovereignty and it is unlikely that they would lose their sense of self in the bargain. The death of the colonial sovereign will grant life to a new sovereign power that will be able to move along the path of reconciliation towards civic equality, which is sadly lacking in the current context. The death of the colonial sovereign might seem extreme, but balanced against completing the destruction of Indigenous peoples, it is an acceptable loss. Such a transformation has a 
much greater likelihood of producing right political relations than reformatory measures conducted by the colonial state.

\section{Acknowledgements}

I would like to thank Alice MacLachlan and Michael Giudice for their helpful comments on early drafts of this paper. I would also like to thank the anonymous reviewers at Studies in Social Justice for their helpful comments.

\section{References}

111th Congress. (2009, January 6). Department of Defense Appropriations Act, 2010. Washington, DC: US Government Publishing Office. Retrieved from www.gpo.gov/fdsys/pkg/BILLS-111hr3326enr/pdf/BILLS-111hr3326enr.pdf

Alfred, T. (2005). Wasáse: Indigenous pathways of action and freedom. Peterborough, ON: Broadview Press.

Alfred, T., \& Corntassel, J. (2005). Being Indigenous: Resurgences against contemporary colonialism. Government \& Opposition, 40(4), 597-614.

Anghie, A. (1996). Francisco de Vitoria and the colonial origins of international law. Social \& Legal Studies, 5(3), 321-336.

Anghie, A. (1999). Finding the peripheries: Sovereignty and colonialism in nineteenth-century international law. Harvard International Law Journal, 40(1), 1-80.

Anderson, B. (2006). Imagined communities. New York: Verso.

Atleo, S. (2012). The economics of reconciliation. Speech to the Assembly of First Nations, The Canadian Club of Toronto, Toronto, 23 April, 2012. Retrieved from www.afn.ca/uploads/files/nc/notescdnclub.pdf

Borrows, J. (2002). Recovering Canada: The resurgence of Indigenous law. Toronto: University of Toronto Press.

Chatterjee, P. (1993). Nationalist thought and the colonial world: A derivative discourse. London: Zed Books.

Coulthard, G. S. (2014). Red skin white masks: Rejecting the colonial politics of recognition. Minneapolis, MN: University of Minnesota Press.

Champagne, D. (2005). Rethinking Native relations with contemporary nation-states. In D. Champagne, K. J. Torjesen \& S. Steiner (Eds.), Indigenous peoples and the modern state (pp. 3-23). Walnut Creek, CA: AltaMira Press.

Foster, D. (1997, February 27). Intermarriage clouds claims of Indian ancestry. Milwakee Journal Sentinal, pp. 13A-n, 14A.

Gray, D. C. (2010). Extraordinary justice. Alabama Law Review, 62(1), 55-109.

Grotius, H. (2012). On the law of war and peace. S. C. Neff (Ed.). New York: Cambridge University Press.

Harding, A. (2018, May 30). South Africans' anger over land set to explode. BBC News. Retrieved from www.bbc.com/news/world-africa-44278164

Keene, E. (2002). Beyond the anarchical society: Grotius, colonialism, and order in world politics. Cambridge: Cambridge University Press.

Kickingbird, K. (1995). What's past is prologue: The status and contemporary relevance of American Indian treaties. St. Thomas Law Review, 7, 603-629.

Lawrence, B. (2004). 'Real' Indians and others: Mixed-blood urban Native peoples and Indigenous nationhood. Lincoln, NE: University of Nebraska Press.

Lawrence, B., \& Dua, E. (2005). Decolonizing antiracism. Social Justice, 32(4), 120-143.

Lorimer, J. (1883). The institutes of the law of nations: A treatise of the jural relations of separate political communities (Vol. 1). London: Blackwood \& Sons.

MacLachlan, A. (2012). The philosophical controversy over political forgiveness. In P. van Tongeren, N. Doorn \& B. van Stokkom (Eds.), Public forgiveness in post-conflict contexts (pp. 37-64). Cambridge: Intersentia. 
Mamdani, M. (1996). Reconciliation without justice. Southern African Review of Books, 46, 3-5.

Moellendorf, D. (2007). Reconciliation as a political value. Journal of Social Philosophy, 38(2), 205-221.

Moloney, P. (2011). Hobbes, savagery, and international anarchy. The American Political Science Review, 105(1), 189-204.

New Zealand Parliamentary Library. (2009). The origins of the Maori seats. New Zealand Parliamentary Research Papers. Retrieved from www.parliament.nz/en/pb/researchpapers/document/00PLLawRP03141/origins-of-the-m\%C4\%81ori-seats

Rudd, K. (2008, February 12). Full Text: Apology to Aborigines. BBC News. Retrieved from http://news.bbc.co.uk/2/hi/asia-pacific/7242057.stm

Sanderson, D. (2018). Truth and reconciliation in academia: What role for non-Indigenous researchers? Plenary lecture presented at the Annual Meetings of the Canadian Philosophical Association, Montreal, QC.

Sanderson, D. (2014). Overlapping consensus, legislative reform and the Indian Act. Queen's Law Journal, 39(2), 511-550.

Smith, A. (2005). Conquest: Sexual violence and American Indian genocide. Durham, NC: Duke University Press.

Taylor, C. (1998). Modes of secularism. In R. Bhargava (Ed.), Secularism and its critics (pp. 3153). New Delhi, IN: Oxford University Press.

Teitel, R. G. (2000), Transitional Justice. New York: Oxford University Press.

Truth and Reconciliation Commission of Canada. 2015. Honouring the truth, reconciling for the future: Summary of the final report of the Truth and Reconciliation Commission of Canada. Retrieved from http://nctr.ca/assets/reports/Final\%20Reports/Executive_Summary_English_Web.pdf

Uribe, J. (2010). A study on the relationship between Canadian Aboriginal peoples and the Canadian state. Ottawa, ON: Canadian Foundation for the Americas. Retrieved from hwww.focal.ca/pdf/Aboriginals_Uribe_Relationship\%20Canadian\%20Aboriginal\%20Peop les\%20and\%20Canadian\%20State_March\%202006.pdf

Valaskakis, G. G. (2000). Blood borders: Being Indian and belonging. In P. Gilroy, L. Grossberg \& A. McRobbie (Eds.), Without guarantees: In Honour of Stuart Hall (pp. 388-394). London: Verso.

Verdeja, E. (2007). A normative theory of reparations in transitional justice. In C. Card \& A.T. Marsoobian (Eds.), Genocide's aftermath: Responsibility and repair. Malden, MA: Blackwell.

Wiessner, S. (1995). American Indian treaties and modern international law. St. Thomas Law Review, 7, 567-602.

Zinn, H. (2003). A people's history of the United States. New York: Perennial Classics. 